\title{
O patriotismo nos Estados Unidos
}

IRLENA MalHeiros

MONALiSA Lima

Andréa CAmerino

Resumo: Na formação da sociedade estadunidense, influenciada por valores de igualdade e liberdade, o "amor à pátria" tornou-se fundamental articulador das relações internas e externas. Atualmente, as decisões econômicas, políticas, sociais e bélicas continuam permeadas pelo ideal patriótico da Independência que cumpre o papel de sustentáculo da unidade nacional e do poderio internacional.

Palavras-chave: Patriotismo; Democracia; Relações internacionais; EUA.

\section{IrLenA Malheiros \\ Monalisa Lima Andréa Camerino}

Discentes do Mestrado Acadêmico em Políticas Públicas e Sociedade da UECE.

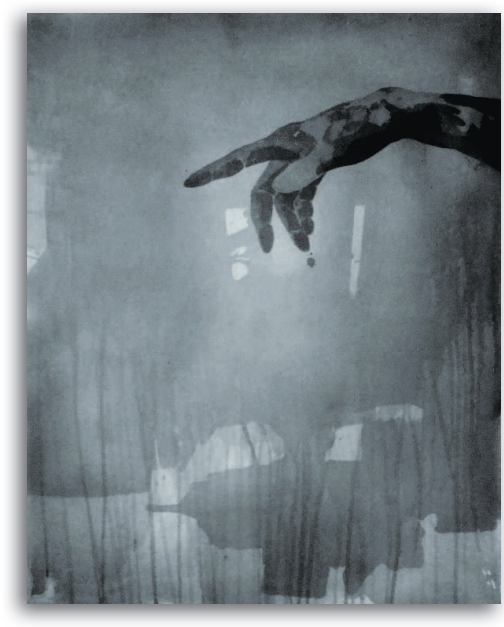

Abstract: In the formation of American society, influenced by values of equality and freedom, the "love of country" has become key articulator of internal and external relations. Currently, economic, political, social and war decisions continue to be permeated by the patriotic ideal of Independence that fulfills the role of mainstay of national unity and international power.

Keywords: Patriotism; Democracy; International Relations; U.S. 


\section{INTRODUÇÃO}

O liberal Aléxis Charles Henri Maurice Clérel de Tocqueville nasceu em uma família tradicional e aristocrática francesa em 1805. No início de 1831, conseguiu autorização do governo do seu país para, ao lado de Gustave de Beaumont, estudar e analisar o sistema penitenciário dos Estados Unidos da América, onde permaneceu por nove meses. Após seu retorno à Europa, publicou em 1933 a referida pesquisa e dois anos depois a primeira parte do seu mais conhecido livro A democracia na América. Somente em 1840 a segunda parte deste é publicada.

A democracia na América, um dos grandes clássicos da ciência política mundial, utiliza-se de uma rica metodologia como, por exemplo, entrevistas e documentação histórica. Seu autor descreveu e analisou profundamente a sociedade política e civil do que hoje é apenas uma parte dos EUA que conhecemos.

Ao discursar criteriosamente sobre a liberdade e a igualdade, o autor remete à questão central da sua obra: será possível a liberdade sobreviver com a presença da igualdade? No entendimento tocquevilleano, a igualdade é a base da democracia e, como defendia a importância da liberdade na sociedade, ele procurava discutir os vigores e as debilidades advindos do regime democrático, sendo sua preocupação maior a possibilidade de um equilíbrio entre igualdade e liberdade.

Este clássico é apontado por muitos estudiosos como uma obra-prima que ainda hoje fornece subsídios para a compreensão das relações de poder internacionais da nossa época. Neste sentido, a partir da visão tocquevilleana e do diálogo com outros autores, pretendemos compreender as relações entre a democracia e o patriotismo nos EUA e que influências essas relações trazem para o resto mundo.

\section{ALÉXIS DE TOCQUEVILLE E A DEMOCRACIA NORTE- AMERICANA}

Pensar as revoluções burguesas no século XVIII implica verificar transformações no referente não só à economia como à política, ao universo das leis, da religião, da ciência, da cultura, ou seja, mudanças nas mais diversas esferas da sociedade ocidental. 
Entre elas, pode-se observar o renascimento da democracia como regime político ideal, porquanto as exigências decorrentes desse novo contexto, cujos princípios básicos eram as ideias de igualdade e liberdade, impunham novos modelos de interação homem-homem assim como homem-Estado. Interações sociais estas que priorizavam o tratamento igual para todos, diferentes daquelas baseadas nos privilégios feudais, característicos do Antigo Regime.

Entretanto, após a Revolução Francesa em 1789, observou-se que a disseminação dos ideais burgueses de liberdade e igualdade por toda a Europa não foram suficientes para a implantação do regime democrático nas mais diversas nações. Isso ocorreu porque, após as "revoluções burguesas" e a conquista dos direitos de igualdade entre os cidadãos, houve, segundo a análise feita por Tocqueville (1998), a ascensão de governos monárquicos/autoritários. Tem-se como exemplo a própria França que, como ícone dos ideais burgueses, mesmo depois de implantar a Declaração dos Direitos do Homem e do Cidadão, viveu o período conhecido como "O Terror"1 seguido pelo governo de Napoleão Bonaparte. Dentro desta perspectiva, como foi possível o estabelecimento da democracia nos EUA?

Em sua estada nos EUA, Tocqueville percebeu um fenômeno singular: todos os norte-americanos se sentiam iguais e livres. Não havia privilégios herdados e títulos de nobreza. As leis eram válidas para todos independentemente de sobrenome, boa educação ou riqueza e todos poderiam frequentar os mesmos ambientes sociais. As atitudes individuais poderiam ser sérias e graves, mas nunca eram arrogantes ou constrangedoras. Não havia jogo de interesses e as relações sociais internas eram mais pacíficas. E como não havia desigualdade herdada, cada um se preocupava com suas próprias necessidades e se sentia livre para supri-las, desde que não ferisse as leis.

\footnotetext{
1 O "Reino do Terror" (ou "O Terror") foi um período da Revolução Francesa, compreendido entre 1793 e 1794, no qual as garantias civis foram suspensas e os opositores foram perseguidos para garantir a manutenção do governo revolucionário. O apoio da população foi conquistado com a promulgação de leis de assistência e de preservação dos direitos humanos estabelecidos pela Revolução (liberdade, igualdade, fraternidade) (COTRIM, 2005).
} 
É interessante destacar que, na ótica tocquevilleana, a abordagem de conceitos como igualdade e liberdade é substancialmente importante no referente ao nascimento de uma sociedade impessoal: as relações políticas, econômicas, religiosas sociais não são mais patrimoniais, baseadas na tradição ou nas relações pessoais e/ou de intimidade, típicas do período medieval e/ou monárquico. Essa nova sociedade que emerge traz como características o individualismo e a racionalidade, onde esta racionalidade permeia os mais diversos aspectos da vida social americana, inclusive a religião, conforme será abordado a seguir.

As leis, exigências dessa nova ordem social essencialmente burguesa e impessoal, existiam para garantir que todos se sentissem livres e iguais. Esse sentimento influenciou também as relações de trabalho. Havia menos distinção e menor distância entre patrão e empregado. Quaisquer desigualdades que surgissem estavam relacionadas à acumulação de dinheiro. Por essa razão, o empregado compreendia que pelo trabalho poderia enriquecer como o seu patrão, conquanto sua ambição fosse compensada com atitudes éticas. Se ainda houver grande diferença entre trabalhador e patrão é por causa dos resquícios aristocráticos, que na democracia logo se extinguirão.

Julgo que, no todo, pode-se asseverar que o aumento lento e gradual dos salários é uma das leis gerais das comunidades democráticas. À medida que as condições sociais se tornam mais iguais, os salários sobem e à medida que os salários tornam-se mais elevados, as condições sociais tornam-se mais iguais (TOCQUEVILLE, 1969, p. 262).

Também os contornos da família foram igualmente delineados de acordo com o sentimento de igualdade e liberdade. A necessidade de criar filhos independentes e trabalhadores enfraqueceu a autoridade paterna. Por isso, quando a criança começava a compreender o mundo sentia-se à vontade para traçar seus próprios caminhos, tendo inclusive o aval dos seus pais sem precisar de qualquer luta doméstica (não havia então adolescência). Isto é fruto da "Lei de Herança" que exterminava o benefício da herança da primogenitura, rompendo com o sentimento aristocrático de família e, consequentemente, com a preservação da propriedade. Os filhos (homens ou mulheres) e os demais residentes partilhavam da 
mesma terra que se tornava cada vez menor em suas dimensões após o falecimento do seu respectivo proprietário.

Essa noção de independência individual surgiu principalmente com a igualdade entre os sexos. Como percebeu Tocqueville, as mulheres cresciam conhecendo os perigos do mundo. Com exceção de algumas localidades do país onde a escravidão era legitimada, ${ }^{2}$ os EUA tinham apreço pela igualdade entre todos os cidadãos. Homens e mulheres eram iguais perante a lei. Isso não significava que os papéis sociais eram os mesmos, mas que todos deveriam cumprir as normas estabelecidas naquela sociedade segundo o que lhes competia. A mulher nascia livre e aprendia desde cedo a se defender. Somente com o casamento essa liberdade era restringida. Na igualdade a tendência de homens e mulheres é se individualizar cada vez mais.

O individualismo é uma marca da sociedade moderna ocidental e funda-se na igualdade e na liberdade. Para o antropólogo Louis Dumont (1992), existem dois significados para o termo "indivíduo": o indivíduo como um sujeito da espécie humana e o indivíduo produzido pela ideologia moderna. O primeiro diz respeito ao ser humano empírico que fala, pensa, deseja e associa-se ao mundo. Ele é extramundano e está ligado ao pensamento social tradicional e hierárquico. O segundo é o ser autônomo, elementar, indivisível, independente e não-social. É intramundano e teve influências da Reforma Protestante, quando a salvação passou a ser buscada no próprio mundo material. Enquanto o primeiro é o ser holista da sociedade tradicional indiana (ou católica europeia), o segundo é o ser individualista da sociedade moderna democrática ocidental.

As transformações sociais modernas fizeram as posições sociais hierárquicas baseadas na tradição ceder seu lugar à liberdade e à igualdade de uma vida social individual. Assim, valores, crenças, títulos de nobreza são abolidos e em troca surgem as necessidades e conquistas pessoais. Os indivíduos desagregam-se da sociedade, "habituam-se a pensar que estão sozinhos, que dependem de si próprios, e imaginam que têm o destino em

2 Os Estados do sul, onde a colonização foi de exploração, tinham maiores resquícios do regime aristocrático. Como a sociedade era tradicional e escravocrata, dificultou o estabelecimento da democracia. 
suas próprias mãos" (TOCQUEVILE, 1969, p. 224-225). "O que se chama ainda de sociedade é o meio, a vida de cada um é o fim" (DUMONT, 1992, p. 57). É essa independência firmada na igualdade que está presente na sociedade norte-americana.

A igualdade de condições, segundo Tocqueville, é um dos alicerces da democracia. Em um sistema democrático, todos os indivíduos precisam sentir-se socialmente iguais (mesmo sendo naturalmente diferentes), compartilhando uma sólida base moral racionalizada, sacralizada e ensinada no seio da família, na escola e nos outros ambientes sociais. Não caberia, então, ao Estado a imposição das normas sociais éticas, pois elas simplesmente se fazem presentes.

Nos EUA, a base moral capitalista e democrática está intimamente relacionada à ética protestante. Nesse prisma, o mandamento "Amai ao teu próximo como a ti mesmo" fundamentou a igualdade de condições nos costumes e nas instituições sociais (todos são iguais perante Deus, mas somente os merecedores terão o reino dos céus). Já a vocação para o trabalho como dádiva divina e, por isso, um dever a ser cumprido com dedicação e ética ajudou a desenvolver o "espírito" capitalista (WEBER, 2004), no qual regem dois princípios fundamentais: acumulação e individualização.

Cabe aqui refletir sobre o que Tocqueville entende como a inter-relação entre democracia e religião. Na medida em que a democracia fomenta nos homens sentimentos de igualdade faz com que sua relação com o mundo seja mediada pela racionalidade. Dogmas, explicações baseadas no sobrenatural não são mais aceitos e a própria religião acaba por se impor limites e admitir, em certo grau, a racionalidade. Em sua ética, passa a reconhecer a busca pelo bem- estar (e a riqueza) como um prêmio de Deus aos que cumprem seu dever e sua vocação profissional com dedicação e merecimento. Assim, uma das maiores contribuições de Tocqueville para a análise sobre a democracia é o fato de perceber a complementaridade entre o mundo político-social e religioso, em uma relação quase simbiótica entre religião e regime político. Dessa forma, consoante afirma, o sucesso da democracia na América se deu, em parte, pela aliança entre os ideais da democracia e a ética protestante.

Ao tecer um paralelo entre a ética protestante americana e a ética cristã brasileira (ou mesmo a católica europeia), é possível 
observar que a primeira cresceu junto ao espírito democrático da sua nação. Logo, até a maneira de "externalizar o amor ao próximo" tem como referência o indivíduo - parte de um indivíduo para outro. Dessa maneira, tal auxílio é prestado de modo indireto, pragmático e quase anônimo. O fruto do bom trabalho do protestante irá beneficiar por si só, segundo sua ética, outrem. No caso brasileiro, a ética cristã (principalmente a católica) prega a ideia segundo a qual o amor ao próximo deve ser realizado de maneira direta, por meio da esmola, da caridade. Assim, o franciscanismo da doutrina católico-cristã brasileira se realiza na pessoa.

Tocqueville, em sua obra, demonstra um temor ao que denomina de "os males da igualdade extrema". Sua preocupação decorre do fato de que uma extrema igualdade poderia conduzir os homens ao individualismo. Na sua perspectiva, em períodos de igualdade, todos os homens buscam, pelo esforço do seu intelecto, as respostas em si. Isto faz com que acabem se fechando em seu próprio mundo, se isolando do resto da sociedade e deixando a cargo do Estado (ou da maioria que não se afastou do convívio dos seus semelhantes) a responsabilidade de decidir sobre todos os assuntos relativos à vida pública. Por conseguinte, leva a sociedade inteira ao despotismo (por parte do Estado) ou à tirania da maioria.

Entretanto o individualismo, de acordo com a concepção a nortear este artigo, é inerente às democracias modernas. O indivíduo é o lugar que comporta as peculiaridades da sociedade ocidental capitalista. É uma construção social, filosófica, política, religiosa, econômica e como tal é o ponto central da elaboração ideológica da nossa sociedade (DAMATTA, 1997). Comporta o anonimato característico de um universo de estranhos, isolado em seus mundos particulares já que independentes e autônomos. E referidos aspectos podem ser notados tanto no tocante ao mundo secular quanto ao transcendental, pois o próprio culto religioso (protestantismo americano) não depende mais do intermédio de sacerdote. Daí o Estado atuar impessoalmente, porquanto servirá a essa sociedade composta por seres anônimos e iguais em direitos e deveres.

Nossas ideias cardinais chamam-se igualdade e liberdade. Elas supõem como princípio único e representação valorizada a ideia do indivíduo humano: a humanidade é constituída de homens, e cada um desses homens é concebido como apresen- 
tando, apesar de suas particularidades e fora dela, a essência da humanidade. [...] esse indivíduo é quase sagrado, absoluto; não possui nada acima de suas exigências legítimas [daí deriva a concepção do indivíduo como um corpo, sendo o Estado pensado/criado para servi-lo]; seus direitos só são limitados pelos direitos idênticos dos outros. Uma mônada, em suma, e todo grupo humano é constituído de mônadas da espécie sem que o problema da harmonia entre essas mônadas se coloque vez alguma para o senso comum (DUMONT, 1992, p. 52-53).

O receio de Tocqueville é que a igualdade ao extremo provoque o que Sennett, no século seguinte, identificou como o "esvaziamento dos espaços públicos" (1988). Em outras palavras, a massificação dos homens (ou os males da igualdade ao extremo, parafraseando Tocqueville) provocou um grande trauma social, só evitável no isolamento do/no domínio privado. O recuo à esfera particular fez com que os espaços públicos deixassem de ser lugares de interação social (e aqui pode-se acrescentar, lugar de exercício das atividades políticas) para se transformar em (meros) ambientes de passagem.

Contudo, mesmo fundamentando seu conceito de democracia na igualdade, para Tocqueville, essa igualdade, quando toma proporções extremas, pode fortalecer demais o poder central, formar uma massa de cidadãos servis ao Estado e inibir a liberdade. Eis o perigo da criação de um governo despótico ${ }^{3}$ em uma democracia:

Acima dessa corrida de homens, ergue-se um imenso poder tutelar que, sozinho, toma a si o encargo de garantir a satisfação de seus desejos e de prestar vigilância sobre seu destino. Esse poder é absoluto, minucioso, regular, providente e brando. Seria uma autoridade de um pai [...] tal governo trabalha com prazer, mas reserva-se de ser o único agente e o único árbitro dessa felicidade [...]. Depois de ter assim apoderado, sucessivamente, de cada um dos membros da sociedade com sua imensa força e de os ter moldado à vontade, o poder supremo estende então seu braço sobre a sociedade inteira. Cobre a superfície da sociedade com uma rede emaranhada de pequenas regras complicadas, minuciosas e uniformes, através das quais os espíritos mais originais e os caracteres mais enérgicos não podem penetrar, para se erguerem acima da multidão. A vontade do homem não é despedaçada, mas amaciada, dobrada e guiada; raras

3 "A espécie de opressão que ameaça as nações democráticas é diferente de tudo que jamais tenha existido no mundo [...] as velhas palavras despotismo e tirania não são apropriadas; a coisa é em si mesma nova" (TOCQUEVILLE, 1969, p. 348). Mas Tocqueville não havia encontrado uma nova palavra para o fenômeno. 
vezes são os homens forçados a agir voluntariamente, mas são constantemente impedidos de agir; esse imenso poder não destrói, mas impede a existência; não tiraniza, mas comprime, enerva, extingue e estupidifica o povo, até cada nação ficar reduzida a não ser nada melhor do que um rebanho de animais industriosos e tímidos, cujo pastor é o governo (TOCQUEVILLE, 1969, p. 349).

Porém, esse poder centralizado, segundo o autor francês, deve intervir apenas nos grandes negócios. Em geral, não há espaço para a intervenção na vida privada dos indivíduos. Entretanto, diante de qualquer sentimento de ameaça à nação, o governo central autoriza-se a prender, intimidar e invadir a intimidade de qualquer cidadão. A liberdade, nesses casos, ficaria ameaçada em nome da proteção nacional.

Então, como fazer a liberdade emergir em sociedades democráticas? Que espécie de governo livre seria possível em um povo de condições sociais tão iguais? Dividindo o poder supremo, diz Tocqueville, e atribuindo parte desse poder a corpos públicos secundários compostos por cidadãos privados com mandatos eletivos e temporários. É exatamente para proteger as sociedades democráticas dos malefícios da igualdade que o autor destaca a importância das associações políticas (onde os indivíduos unir-se-iam em favor dos interesses de pequenos círculos sociais), da liberdade de imprensa (que denunciaria injustiças) e do Poder Judiciário (defensor das leis). É importante ressaltar, inclusive, que essa liberdade observada por Tocqueville nada tem a ver com a escravidão existente nos EUA naquela época. Pelo contrário, o cientista francês, ao observar a escravidão na contramão das tendências norte-americanas, afirmou que tal prática seria um grande problema futuramente, mesmo quando os negros fossem libertados. Ele previu a guerra entre norte e sul e a posterior cultura discriminatória contra negros naquele país.

Ainda conforme Tocqueville, ao mesmo tempo em que a democracia torna todos os indivíduos socialmente iguais, ela os divide naturalmente. Isso acontece porque:

[...] as instituições podem mudar, mas o homem não; seja qual for a tentativa geral da comunidade tornar os seus membros iguais e indistinguíveis, o orgulho pessoal dos indivíduos tentará sempre subir acima da linha e criar de alguma maneira uma 
desigualdade em seu próprio benefício [...]. Assim, seja qual for o progresso da igualdade, nas nações democráticas haverá sempre um grande número de pequenas associações privadas dentro do palco geral da sociedade política, mas nenhuma dela terá qualquer semelhança nas suas maneiras com a classe mais elevada das aristocracias (TOCQUEVILLE, 1969, p. 285).

A importância desses grupos secundários de poder seria, então, a fiscalização do governo central, a segurança do cumprimento às leis e a garantia da liberdade das minorias. Em Tocqueville, a democracia é representativa.

Os EUA foram fundados alheios ao sistema aristocrático europeu. Portanto, apesar da colonização inglesa, eles se formaram sem as influências dos privilégios de nascimento e de riqueza. Todos os indivíduos eram livres e iguais. Como o autor afirma, a democracia tornava a convivência entre os norte-americanos simples e fácil.

Contudo, enquanto a democracia cria uma convivência interna mais pacífica, fortalece a vaidade em suas relações externas. Como os EUA se tornaram o primeiro país no mundo a vivenciar profundamente os ideais democráticos (os países europeus ainda lutavam pelo estabelecimento da democracia) e como os indivíduos sentiam-se responsáveis pelos rumos da sua terra (consequência da soberania popular), o "amor à pátria" teve terreno fértil para prosperar. Nessa ótica, o orgulho nacional confundia-se com o orgulho individual.

Nos Estados Unidos, a pátria faz-se sentir por toda parte. É objeto de anseios desde a aldeia até a União inteira. O habitante liga-se a cada um dos interesses de seu país como aos seus próprios. Glorifica-se na glória da nação; no triunfo que ela obtém, julga reconhecer a sua própria obra e nela se eleva; rejubila-se com a prosperidade geral da qual tira proveito. Tem por sua pátria um sentimento análogo àquele que experimentamos pela família, e é ainda por uma espécie de egoísmo que se interessa pelo Estado (TOCQUEVILLE, 1998, p.79).

A democracia despertava nos cidadãos forte sentimento de pertença e união. O patriotismo era ardente, ciumento e vingativo. Em face de uma ofensa à honra nacional, os indivíduos esqueciam qualquer diferença interna e uniam-se para o fortalecimento do governo central e a defesa da sua pátria. Eis o motivo pelo qual o governo federal agia diretamente nos assuntos internacionais: a defesa dos interesses do país diante do mundo. 
Mesmo com essa tendência patriótica, as sociedades democráticas tendem naturalmente, segundo o autor, a preferir a manutenção da paz. Isso se dá pelo princípio da igualdade: na medida em que a democracia se espalha pelos países, os interesses sociais, econômicos, políticos e culturais entre as nações se tornam semelhantes. Assim, ficaria mais difícil haver hostilidade entre as nações. Mas também quando há hostilidade entre duas delas, a tendência é as outras serem arrastadas por conta de interesses comuns (formação de blocos). "As guerras tornam-se, portanto, mais raras, mas quando eclodem, espalham-se por um campo maior" (TOCQUEVILLE, 1969, p. 327).

\section{AS INFLUÊNCIAS DO PATRIOTISMO NAS RELAÇÕES DOS EUA COM O MUNDO CONTEMPORÂNEO}

Ao longo do tempo, o patriotismo tem sido uma das características mais visíveis nas imagens que nos são passadas sobre os EUA e surgiu com grande frequência nos questionamentos advindos da leitura do livro A democracia na América, já que para Tocqueville o "amor à pátria" era extremamente relevante na formação da sociedade norte-americana.

Em O príncipe, Maquiavel (1992) já sinalizava para a importância do patriotismo (embora não utilizasse esse termo). Nas instruções que ele faz a Médici sugere a formação de uma força militar composta por cidadãos (em oposição aos exércitos mercenários), onde os soldados defenderiam os interesses do Estado por amor, chegando a ponto de entregar sua vida pelo país.

Definido como a união de sentimento de afeto e compromisso moral em relação a um determinado território, a partir da qual surge uma aspiração de defendê-lo contra qualquer perigo externo mesmo antes dele existir, o patriotismo é estimulado nos norte-americanos desde o seu nascimento, tendo como símbolo máximo sua bandeira. ${ }^{4}$ Essa característica tão marcante se faz presente desde a época da formação colonial e, segundo Tocqueville, foi fundamental na construção e manutenção de tal sociedade, por ter dado o ânimo necessário para um desenvolvimento

4 Pintada com as cores da Revolução Francesa. 
social, econômico e político. O "amor à pátria" fazia com que os norte-americanos acreditassem ser seu país uma família e que todos os habitantes eram irmãos por terem origem semelhante e o mesmo ideal: "fazer a América" - construir um país próspero e rico, mediante muito trabalho, disciplina e fé (puritanismo).

O sentimento nacionalista que mantém a dinâmica social estadunidense ultrapassou o tempo e ainda é cultivado por meio de discursos políticos, pela mídia, o ensino nas escolas. Transformouse em um dos principais mecanismos de manutenção da ordem social vigente a serviço de interesses políticos internos como, por exemplo, a tentativa de formar (ou manter) uma identidade nacional, de fomentar a autoestima norte-americana em épocas de crises e de justificar a política externa. É por isso que o "amor à pátria" tem aparecido nos principais marcos históricos do país, como na Declaração de Independência (1776) e na Guerra de Independência (1776-1783), por exemplo. Para fins deste artigo, discutiremos as questões norte-americanas da atualidade.

A decadência do regime comunista no final da década de 1980 consolidou a emergência dos EUA como a grande liderança mundial. O sistema capitalista e o regime democrático, simbolizado pelo American way of life, tornaram-se hegemônicos, o que trouxe ao mundo profundas mudanças sociais, culturais e políticas. Esse estilo americano de vida expressa um suposto comportamento típico dos cidadãos norte-americanos. Existe desde a formação nacional, mas foi bastante utilizado pela mídia durante a Guerra Fria e, principalmente, logo após a queda no regime comunista com o objetivo de difundir uma identidade nacional baseada na ideia de democracia e liberdade. Influenciou profundamente o chamado American dream, ou seja, o sonho da felicidade se realizava somente na adesão ao estilo de vida americano. É como se, segundo Jameson Fredric e Slavoj Zizek (1998), a identidade ideológica de "ser americano" superasse a tensão existente entre as diferenças étnicas individuais e a identidade coletiva (ideal de igualdade). Foi a partir daí que o país se tornou o "tio" 5 protetor do mundo.

La clave de la "Ideología Americana" estándar radica en que intenta transustanciar la fidelidad que se tiene hacia las raíces de

5 Tio Sam é um dos símbolos mais famosos dos EUA. 
la etnia propia en una de las expresiones del "ser americano": para ser un buen americano, uno no tiene que renunciar a sus propias raíces étnicas - los italianos, los alemanes, los negros, los judíos, los griegos, los coreanos, son "todos americanos", es decir, la particularidad misma de su identidad étnica, la forma en que se aferran a ella, los hace americanos (FREDRIC; ZIZEK, 1998, p. 19).

Durante a década seguinte, enquanto o estilo de vida americano era imposto como moda, as diferentes identidades espalhadas pelo mundo reagiam ora pelo ódio ora pela servidão. E, em 11 de setembro de 2001 - quando aviões foram sequestrados e utilizados para atacar o World Trade Center e o Pentágono - os EUA sentiram o peso da resistência do mundo árabe ao American way of life. Tais atentados instalaram novas perspectivas para o mundo e desde então a crise social, política e econômica norte-americana só se agrava.

O discurso patriótico marcou a eclosão da "guerra contra o terror". O então presidente George W. Bush liderou um movimento de vingança sob a justificativa de que os EUA, a partir daquele momento, libertariam o mundo da opressão e do chamado terrorismo. Em pronunciamento analisado por Feitosa (2008, p. 157), Bush afirmou que

[...] America speaks anew to the peoples of the world: All who live in tyranny and hopelessness can know: the United States will not ignore your oppression, or excuse your oppressors. When you stand for your liberty, we will stand with you.

Desse modo, assumia uma postura, visivelmente patriótica, de principal liderança mundial e de exemplo do caminho correto.

Abalados com os atentados, os norte-americanos demonstraram divergências nas opiniões sobre a vingança proposta pelo governo. Surgiram no país tanto movimentos de apoio à guerra (que seria iniciada contra o Afeganistão ainda em 2001) quanto à paz (MARTINS, 2006). A postura de Bush obteve apoio interno na medida em que seu discurso atuou sobre a memória discursiva da população norte-americana: a utilização cuidadosa em seus pronunciamentos de palavras-chave da Declaração de Independência, evidenciando os valores do American way of life como democracia, liberdade, igualdade, confiança nas instituições e patriotismo (FEITOSA, 2008). Entretanto, tornava-se cada vez mais clara 
a insatisfação dos norte-americanos com o estado de guerra em que o país vivia. Essa restrição ao discurso de Bush se dava: 1) pela crescente ideia de pacificação mundial, principalmente em decorrência das experiências negativas de guerra anteriores como Vietnã; 2) pelo desgaste, citado por Fredric e Zizek (1998), que a ideologia americana tem sofrido desde o desenvolvimento dos Estados-nação e da globalização.

Esta transustanciación por medio de la cual se supera la tensión entre mi identidad étnica particular y mi identidad como miembro del Estado-Nación hoy se ve amenazada: es como si se hubiese erosionado seriamente la carga positiva que tenía la patética identificación patriótica con el marco universal del Estado-Nación (Norteamérica). La "americanez", el hecho de "ser americano", cada vez despierta menos el efecto sublime de sentirse parte de un proyecto ideológico gigantesco, "el sueño americano", de manera que el estado americano se vive cada vez más como un simple marco formal para la coexistencia de una multiplicidad de comunidades étnicas, religiosas o de estilos de vida (FREDRIC; ZIZEK, 1998, p. 19).

Também como destacamos, apesar desse aparente racha interno, a população estadunidense demonstra ainda profunda união em busca de melhorias para seu país. Contraditoriamente, deixa transparecer as diferenças internas no país, indicando as tensões latentes dentro da identidade coletiva de "ser americano", apesar de ser também judeu, mulçumano, cristão, latino, negro, etc.

Conhecedor das divergências internas e da dificuldade de conseguir apoios externo, sobretudo da Organização das Nações Unidas (ONU), ao anunciar a "guerra contra o terror", Bush fez a seguinte observação: "Ou estão conosco ou estão contra nós". Tal frase descreve a realidade de um planeta dividido simbolicamente entre dominantes (cujos interesses da cultura ocidental capitalista são representados pelos EUA) e dominados (minorias étnicas orientais e ocidentais submetidas a processos de dominação cultural, econômica e política, representadas por "terroristas" afegãos). O próprio presidente chamou esse fenômeno de guerra entre Eixo do Bem e Eixo do Mal ou "a cruzada contra o terror" (FEITOSA, 2008).

Os EUA convocaram todo o mundo "civilizado" para lutar ao seu lado contra o terrorismo e em favor da liberdade. O objetivo 
é "lutar pela civilização" e "manter o estilo de vida desfrutado pelos países livres". Em nome dos ideais democráticos, os soldados norte-americanos invadiram o Afeganistão e, posteriormente, o Iraque, símbolos do chamado "Eixo do Mal".

Para Zizek (2001), todo esse embate se explicaria pela compreensão das relações conflituosas entre dominantes (Exterior puro) e dominados (Exterior "bárbaro"). Segundo ele afirma, o modo individualista com que os norte-americanos agem, na busca desenfreada pelo poder, teria levado destruição para muitos povos espalhados pelo mundo. A resolução desse conflito passaria necessariamente pela compreensão dos norte-americanos de que o Exterior "bárbaro" é apenas o reflexo deles mesmos e não um mal separado e independente, pois "nos últimos cinco séculos a prosperidade e paz (relativas) do Ocidente 'civilizado' foram compradas pela exportação de impiedosa violência e destruição ao Exterior 'bárbaro': a longa história desde a conquista da América ao massacre no Congo" (ZIZEK, 2001, p. 3). E, ainda:

As "férias da história" dos EUA foram um embuste: a paz americana foi comprada por meio de catástrofes que aconteceram em outros lugares. Aí reside a verdadeira lição dos atentados: o único modo de assegurar que não acontecerão novamente é evitar que aconteçam em qualquer lugar (ZIZEK, 2001, p. 4).

Ao retornarmos o pronunciamento de Bush citado anteriormente, percebemos como ele caracterizava esse Exterior "bárbaro" (ruim, incorreto, extinguível), estabelecendo um contraponto à ideologia americana (boa, correta, multiplicável) marcada pelo discurso de Abraham Lincoln:

The rulers of outlaw regimes can know that we still believe as Abraham Lincoln did: "Those who deny freedom to others deserve it not for themselves; and, under the rule of a just God, cannot long retain it". The leaders of governments with long habits of control need to know: To serve your people you must learn to trust them. Start on this journey of progress and justice, and America will walk at your side. And all the allies of the United States can know: we honor your friendship, we rely on your counsel, and we depend on your help. Division among free nations is a primary goal of freedom's enemies. The concerted effort of free nations to promote democracy is a prelude to our enemies' defeat (FEITOSA, 2008, p.157). 
Em artigo escrito no mesmo ano dos ataques aos EUA, Zizek (2001) lançou uma dúvida que somente o tempo responderia: Qual o rumo que os EUA tomariam a partir daqueles acontecimentos? A pergunta do filósofo tem a ver com as reflexões do próprio país sobre as relações de causa e efeito dos atentados: os EUA admitiriam que a guerra nos outros países é a guerra neles ou radicalizariam a paranoia do Exterior "bárbaro" ameaçador? A resposta veio logo em seguida com a invasão ao Afeganistão.

Como podemos perceber, o discurso norte-americano para justificar a invasão do território afegão era a defesa nacional. Bush construiu uma série de elementos simbólicos em busca da legitimação da seguinte ideia: Os EUA seriam um modelo de nação livre, próspera e feliz atacados por povos selvagens reprimidos por governantes agressivos. Mais uma vez, o patriotismo revelou-se fundamental.

Na mesma tendência, Frantz Fanon (1995) analisou a colonização francesa na Argélia e demonstrou como imposições geram as resistências. Consoante o autor, um dos mais marcantes símbolos da resistência argelina durante o conflito foi o véu - uma das vestimentas femininas mais típicas de países de cultura árabe. Aos olhos de um observador, o véu caracteriza a mulher argelina e, muitas vezes, produz uma espécie de curiosidade pelo que existe por trás daqueles tecidos. Para os franceses, tal vestimenta era o símbolo da opressão feminina e, por isso, sua primeira atitude na Argélia foi abolir o véu das ruas com o objetivo de trazer a mulher para o seu lado (já que ela tinha grande importância na sociedade argelina). Contudo, a proibição transformou aquela vestimenta em um dos principais símbolos de resistência: as mulheres usavam o véu em defesa dos seus valores e passaram a participar de conflitos armados contra os invasores.

Outro símbolo da resistência a processos colonizadores é o Tibet. Entretanto, ele optou por uma forma diferente de resistência dos demais exemplos aqui citados. Os tibetanos escolheram a não-utilização da violência, aderindo a uma espécie de diáspora, com vistas a plantar sementes da sua cultura pelo mundo enquanto buscavam, por meio da figura do Dalai Lama e do apoio de outros povos, obrigar a China a permitir que os tibetanos vivessem de acordo com seus costumes. 
O sentimento de superioridade norte-americano conduz suas atitudes interna e externamente. Todas as resoluções tomadas no país caminham no sentido da preservação da sua própria paz e prosperidade, pouco importando as consequências que os outros poderão sofrer. O resultado disso é a resistência dos oprimidos.

Conforme vimos em Tocqueville, o patriotismo surge da igualdade. Segundo Dumont (1992), os preconceitos que permeiam a sociedade americana para com a diferença surgem, principalmente, da igualdade, pois, quando um povo acredita na existência do igualitarismo em sua sociedade, as diferenças naturais no ser humano perdem seu espaço e, por serem inevitáveis, são vistas como algo não pertencente ao que é comum (daí a visão preconceituosa).

A ideologia norte-americana é igualitarista ao máximo. O Credo norte-americano exige a livre competição, que, do ponto de vista da estratificação social, representa uma combinação de duas normas de base: igualdade e liberdade, mas aceita a desigualdade como resultado da competição (DUMONT, 1992, p. 307).

A discriminação surge quando a diferença se revela em uma sociedade baseada no ideal de igualdade, mas com tendência a desenvolver um raciocínio dual - eu e outro. Isso porque a pressuposição de serem todos iguais faz o diverso ser visto como algo ilegítimo e, consequentemente, discriminado. É assim que o autor explica o preconceito sofrido pelas minorias nos EUA. A igualdade seria, então, maléfica em sua própria essência, contrariando a perspectiva de Tocqueville de que somente a forma exacerbada da igualdade - a tirania da maioria - é que seria prejudicial, ${ }^{6}$ já que a divisão desencadeada pelas diferenças ditas naturais se resolveria com a formação de associações políticas capazes de fortalecer as minorias e evitar a tirania da maioria.

Tratando-se de política interna, nos tempos de crise, como já previa Tocqueville, os órgãos de controle da tirania da maioria cedem aos discursos patrióticos e podem desviar sua função em nome de um ideal. As associações políticas, a imprensa e o Poder Judiciário ficam à mercê de acusações antipatrióticas

6 Como dito anteriormente, segundo Tocqueville, a democracia divide os indivíduos naturalmente, pois os homens são naturalmente diferentes. Mas essa divisão se resolveria com a formação de associações políticas capazes de fortalecer as minorias e evitar a tirania da maioria. 
caso façam críticas às políticas do governo, caracterizando assim o cerceamento da liberdade das minorias. O jornalismo, por exemplo, acaba servindo mais ao ideal nacional do que ao seu ofício comprometido com a verdade:

Fere-o o mais leve reproche, a menor verdade picante o enfurece; e é preciso que se louvem desde as formas de sua linguagem até as suas mais sólidas virtudes. Nenhum escritor, seja qual for a sua fama, pode escapar a essa obrigação de incensar seus concidadãos. A maioria vive, pois, numa perpétua adoração de si mesma; somente os estrangeiros ou a experiência são ainda capazes de fazer chegar certas verdades aos ouvidos dos americanos (TOCQUEVILLE, 1998, p. 198).

Por isso, as críticas nacionais não são aceitas em tempos de crise. Muitos jornais locais e internacionais informam apenas os dados técnicos da guerra em favor do próprio país e os discursos que dão aos EUA a missão de livrar o mundo do terrorismo. Os mortos aparecem apenas como uma consequência da luta pela liberdade.

Podemos questionar se a divulgação de fotos e vídeos onde aparecem soldados norte-americanos humilhando seus prisioneiros não seria uma forma de resistência da própria imprensa diante da inibição do seu ofício de informar. Sim. Ao mesmo tempo em que a imprensa confirma a legitimidade de discursos patrióticos em favor da guerra, ela age como o que Tocqueville chamou de "corretivo" da igualdade, dando voz à parcela que se declara contra a guerra. Percebemos então uma imprensa livre e ao mesmo tempo presa aos valores morais do seu país.

Uma parte desse nacionalismo é também incentivada pela propaganda. O poder da mídia e do marketing é grandioso. Evidentemente, a sociedade americana não é a perfeição que aparenta - tem problemas como todas as outras sociedades - mas o grande papel da mídia está exatamente em trabalhar nessa aparência, que tanto ilude a comunidade estrangeira como impulsiona o patriotismo dos seus habitantes. Atualmente, por exemplo, em época de grave crise econômica, o discurso do "amor à pátria" tem sido utilizado para impulsionar o mercado interno. Somado a isso, a crise nas políticas interna e externa fez do presidente Barack Obama o poderoso salvador, mais um mito criado pela sociedade norte-americana (especialmente pela mídia). 
As tentativas de reformas internas, a morte de Osama Bin Laden e o anúncio da possível retirada das tropas norte-americanas do Afeganistão são exemplos dos jogos políticos internos para favorecer a ideia de serem os EUA capazes de enfrentar crises e proteger seus cidadãos. Sem a produção desse líder - intelectual negro considerado representante de diversas minorias - a manutenção da ordem interna teria sido mais difícil, pois "simbolizava a aspiração de unidade nacional em um país de imigrantes e ex-escravos, profundamente dividido e desigual" (MARTINS, 2009, p. 1) mesmo que na prática também legitime uma política de falsa igualdade, negadora das diferenças e desigualdades históricas, tal qual mencionada por Fredric e Zizek (1998).

O pronunciamento de Barack Obama é a continuadade [sic] desta visão "daltônica" sobre a América. Ao tempo em que homenageia o movimento pelos direitos civis, claramente oferece uma visão não-racial dos EUA, alinhada com a perspectiva conservadora. Por fim, um político negro pode absolver a América da culpa pelo legado de escravidão e da segregação. Obama não ameaça a América branca confirmando a visão de que os EUA são agora racialmente neutros. Afinal, se os EUA têm um presidente negro, isto não significa verdadeira igualdade de oportunidades? (FRANK, 2008, 323).

Na política internacional, evidenciamos claramente o enfraquecimento dos EUA como líderes mundiais quando o próprio Obama precisou reafirmar em discurso a hegemonia norte-americana no mundo, fato no qual nem ele acredita. O medo está exatamente em que as crises norte-americana e europeia fortaleçam ainda mais países emergentes, como Brasil e China, a ponto de terem legitimidade para reivindicar papéis mais importantes em organismos internacionais como, por exemplo, cadeira permanente no conselho de segurança da Organização das Nações Unidas (ONU).

Outro exemplo das influências atuais do patriotismo exacerbado na liberdade nos EUA é a dificuldade do Poder Judiciário garantir que a intimidade dos moradores do país em discussão seja preservada. Se a igualdade nos EUA deve ser assegurada pelas leis e estas aplicadas a todos igualmente, como fica a democracia em um país onde pessoas são monitoradas, presas e até torturadas em nome da defesa nacional? Seriam os EUA atualmente a 
democracia temida por Tocqueville pautada na tirania da maioria? Estaria Dumont (1992) correto em afirmar que o ideal de igualdade funda as desigualdades que tanto combatemos? Estas questões merecem reflexões futuras.

\section{CONSIDERAÇÕES FINAIS}

A compreensão dos conceitos de Aléxis de Tocqueville acerca da democracia norte-americana é de fundamental importância para algumas análises sobre a atual conjuntura social, política e econômica mundial. Liberdade e igualdade, pilares da democracia ideal tocquevilleana, continuam no imaginário influenciando as formas de agir, pensar e sentir dos norte-americanos. O patriotismo aparece como uma das principais ferramentas para a manutenção do sistema simbólico da democracia.

Em Tocqueville, o grande problema da democracia é a igualdade extrema, pois provocaria um profundo processo de individualização do cidadão, a ponto de afastá-lo do convívio social e minar sua liberdade política. Entendemos, então, que a individualização funcionaria como uma força centrífuga, empurrando o indivíduo para fora da sociedade. Em sentido complementar, conforme observamos, o "amor à pátria" agiria de maneira inversa, como uma força centrípeta na medida em que mantém o indivíduo ligado à sociedade.

Discutir o patriotismo como elo entre os cidadãos e a pátria ajuda a compreender os mecanismos de manutenção da ordem social vigente (a serviço dos interesses internos) seja num momento de crise - para explicar uma política estatal - seja para fortalecer a identidade e a coesão nacionais.

A política externa também é influenciada pelo patriotismo. Nesse caso, o "amor à pátria" é o meio pelo qual os EUA justificam a intervenção social, política, econômica, cultural e militar em outros países. Em nome da democracia, ferem soberanias nacionais, matam pessoas, dominam culturas. Em contrapartida, os movimentos de resistência agem na tentativa de diminuir os impactos da dominação norte-americana em seus países. Esses jogos políticos internacionais fundam-se nessas relações conflituosas ora mediante guerras ora por legitimações simbólicas. 


\section{REFERÊNCIAS}

COTRIM, G. História global: Brasil e geral. 8. ed. São Paulo: Saraiva, 2005.

DAMATTA, R. A casa e a rua: espaço, cidadania, mulher e a morte no Brasil. 5. ed. Rio de Janeiro: Rocco, 1997.

DUMONT, L. Homo hierarquicus. São Paulo: EDUSP, 1992.

FANON, F. A Argélia se desvela. In: CORRÊA, Mariza (Org.).

Três ensaios sobre a Argélia e um comentário. Campinas: UNICAMP, 1995. (Texto Didático, n. 46).

FEITOSA, L. D. Guerra de sentidos: uma leitura dos pronunciamentos do Presidente George W. Bush sobre a guerra com o Iraque. 2008. 163 f. Dissertação (Mestrado em Linguística)

- Programa de Pós-Graduação em Linguística, Universidade de Campinas, Campinas, SP, 2008.

FRANK, J. Raça e eleição nos EUA: comentário ao pronunciamento de Obama. Ten. Mund., Fortaleza, v. 4, n. 6, p. 295-334, jan./jul. 2008.

JAMESON, F.; ZIZEK, S. Estudios culturales. Reflexiones sobre el multiculturalismo. In: ZIZEK, S. Multiculturalismo o la lógica cultural del capitalismo multinacional. Buenos Aires: Paidós, 1998. p. 137-188. Disponível em: <http://www.cholonautas.edu. pe/modulos/biblioteca2.php?Id Documento=0297>.

MAQUIAVEL, N. O príncipe. Brasília: EdUnB, 1992.

MARTINS, M. D. Anseios de uma nação. O Povo, Fortaleza, 18 jan. 2009. Disponível em: <http://www.nacionalidades.ufc.br/ textos/MDM\%20-\%20Anseios \%20de \% 20uma\%20nacao.pdf>.

. A sociedade norte-americana e a guerra.

O Povo, Fortaleza, 5 out. 2006. Disponível em: <http://www. nacionalidades.ufc.br/textos/Monica\%20 Martins_a_sociedade_ norte_americana_e_a_guerra.pdf $>$.

TOCQUeVILle, A. A democracia na América. Belo Horizonte: Itatiaia, 1998.

Democracia na América. Ed. Condensada.

São Paulo: Companhia Nacional, 1969. (Coleção para o Leitor Moderno). 


\section{WEBER, M. A ética protestante e o "espírito" do}

capitalismo. São Paulo: Companhia das Letras, 2004.

ZIZEK, S. Bem vindo ao deserto do real. Folha de São Paulo, São Paulo, 23 set. 2001. Disponível em: <http://slavoj-zizek. blogspot.com/2010/01/bem-vindo-ao-deserto-do-real.html>. 